\title{
A Study on the Application of Happy Teaching Method in the Teaching of Public Aerobics Course in Colleges and Universities
}

\author{
Lizhong Wen \\ College of Sports and Science, Jishou University, Jishou, Hunan 416000 \\ wenlizhong1107@163.com
}

\begin{abstract}
With the continuous deepening of quality education reform, the teaching methods of each stage is becoming more and more perfect, and the happy teaching method is gradually applied to the public sports aerobics course in colleges and universities, which has greatly improved the teaching value of aerobics. This paper uses literature materials, conducts interviews on the application of the happy teaching method of public sports in colleges and universities, and analyzes its necessity. In the end, the paper proposes the correct understanding and scientific formulation of teaching objectives and reasonable integration of teaching content, and emphasizes the application of modular teaching so as to achieve the new requirements of aerobics teaching under the new situation
\end{abstract}

Keywords-Happy Teaching Method; Colleges and Universities; Public Sport; the Teaching of Aerobics Course; Application

\section{INTRODUCTION}

In the new situation, aerobics has become an indispensable key content in the public physical education teaching in colleges and universities, and is deeply loved by students at all levels. How to improve the teaching efficiency and quality of aerobics courses has become a major problem that teachers urgently need to solve. Deepening the teaching mode is an essential and important link. In daily teaching, teachers should deeply analyze the teaching problems of aerobics course and flexibly apply the happy teaching method to encourage students to learn the theoretical knowledge of aerobics easily, master the skills of aerobics, exercise their bodies and, at the same time, improve the comprehensive quality of physical education in the process of experiencing the fun of aerobics, so as to carry out the concept of happy sports smoothly and present the art charm of public sports aerobics classroom objectively.

\section{THE NECESSITY OF APPLYING HAPPY TEACHING METHOD IN THE TEACHING OF PUBLIC AEROBICS COURSE IN COLLEGES AND UNIVERSITIES}

Under the new situation, the traditional teaching mode has been unable to meet the specific teaching requirements of the public sports aerobics course. It does not pay attention to the manifestation of the students' main position, blindly instructs the students to practice repeatedly, so that the aerobics loses its original vitality, the happy elements in aerobics class are constantly lost, students are in a passive learning state and the teaching effect of aerobics is not high, which affect the smooth realization of teaching objectives in various stages and the concept of quality education and lifelong physical education cannot be implemented. At the same time, The happiness teaching method has the superiority which the traditional single teaching mode can not be compared with, so it is very essential to flexibly apply it to the each links of teaching of public sports aerobics course in colleges and universities. It is conducive to changing the role of teachers and students scientifically, letting students be the "master" of the classroom and constructing the student-oriented classroom successfully and the harmonious new teacher-student relationship, which accords with the inherent requirements of student-centered teaching under the background of quality education. The application of happy teaching method is conducive to improving the fun degree of aerobics class, letting students be interested in learning aerobics in the happy teaching situation, integrate into aerobics theory and practice teaching actively, excavate all aspects of their potential, understand the standardized aerobics movements on the basis of theoretical knowledge of aerobics, master the necessary skills, promote the development of all aspects of the ability easily and better present individuality in aerobics practice. The application of the happy teaching method can promote the practical value of the teaching of public sports aerobics course in colleges and universities and promote the development of the teaching of public aerobics course towards the socialization direction in the new period. 


\section{THE APPLICATION PATH OF HAPPY TEACHING METHOD IN THE TEACHING OF PUBLIC SPORTS AEROBICS COURSE IN COLLEGES AND UNIVERSITIES}

\section{A. To correctly understand and scientifically formulate teaching objectives}

Under the new situation, teachers in colleges and universities should use a brand-new perspective to correctly understand the teaching of public sports aerobics course, put it in the core position of public sports teaching, deeply analyze the teaching function of public sports aerobics under the background of quality education and optimize and innovate the teaching of public sports aerobics by combining with various problems in daily teaching. During this process, teachers should have a correct all-around understanding of happy teaching method, set up happy sports concept, make clear the connotation and importance of happy teaching method, insist on the principle of taking students as the basis, apply happy teaching method to the teaching of public sports aerobics course skillfully and help it add a new vitality to prompt the teaching of public sports aerobics to be more reasonable and effective. In addition, teaching objective is the direction and destination of teaching activities. In the daily teaching process, teachers should take students as the entry point according to the specific application requirements of the happy teaching method on the basis of various problems, scientifically formulate the teaching objective of public sports aerobics course in every stage, clarify the teaching direction of aerobics course and promote the teaching of aerobics in an orderly manner. Teachers should adhere to the principle of teaching students according to their aptitude, revolve around the idea of peopleoriented, pay attention to the development of each student in the class, formulate the distinct teaching objective at different levels, promote the students at all levels in the class to obtain more success and happy experience under the action of the happy teaching method so as to like and fall in love with aerobics and form more good quality in active practice, implement "happy sports" concept and better practice the concept of quality education.

\section{B. To integrate teaching contents reasonably and emphasize modular teaching}

The reasonable integration of teaching contents is the first prerequisite to promote the application value of happy teaching method. In the process of public sports aerobics teaching, teachers should focus on the happy teaching method, put the technology teaching and ability training in the same important position and deepen the teaching structure system of aerobics course that has been built up. Teachers should accurately interpret the requirements of aerobics teaching in every stage from the perspective of cultivating students' ability, reasonably integrate the contents of aerobics courses, scientifically adjust the proportion of various contents and clarify the key points and difficulties of aerobics teaching based on the teaching goal. Teachers should introduce the modern contents which meet the aesthetic needs of college students in the new period, such as fight and Latin aerobics, hip-hop dance and yoga, enrich the teaching contents, skillfully incorporate the elements of happiness into the course, make it more interesting and lively so as to enhance students' recognition of aerobics, mobilize students' enthusiasm for learning and make them blend in the aerobics courses actively under the condition of happy teaching method. In addition, in the process of applying happiness teaching method, teachers should emphasize modular teaching, integrate the scattered calisthenics curriculum knowledge with the help of the teaching structure system that has been built up and conduct special topic teaching of aerobics, which is convenient for students to perfect the knowledge structure system of aerobics that has been built up in real time and gradually accumulate abundant theoretical knowledge of aerobics, in order to supply favorable guarantee for better doing aerobics practices. Teachers should integrate the happy teaching method into classes from the point of view of students according to the modular key points and difficulties of public sports aerobics, carry out the classroom teaching of happy aerobics smoothly and complete the teaching task of aerobics in each stage efficiently.

\section{To change the role of teachers and students and show the students' main position}

In the daily teaching process, teachers should take the happy teaching method as the breakthrough point, change the traditional "one-way, standard, procedural" public sports aerobics teaching methods, change the role of teachers and students in real time, hand over the initiative of aerobics classroom teaching to students, change from "teaching" to "guiding" and help students to learn to grasp the direction, route, and articular coordination of aerobics movements by feeling muscle strength with the help of their own muscle movements under the guidance of aerobics "language" and "action", but not blindly imitate teachers' demonstration actions In applying the happy teaching method, teachers should guide and instruct the students at all levels of the class to analyze and think more in the happy aerobics teaching situation, help them self "discover, analyze, and solve" the problems encountered in understanding the connotation of aerobics movements and mastering skills, constantly summarize the rules of aerobics movement and acquire knowledge and feelings of aerobics, including the fun of learning aerobics, take aerobics as one of the interests and hobbies after class, which will effectively present its main position in the classroom. Teachers only need to give full play to their guidance and instruction role and leave enough development space and time for each student to experience happiness in self-solving calisthenics course. 
D. To skillfully use multimedia technology and optimally use many kinds of teaching methods

In the application of happy teaching method, teachers should skillfully introduce multimedia technology into the teaching of public sports aerobics and objectively present the key points and difficulties in each course section of it with the help of multimedia pictures and texts, in the form of short films, videos, animations, etc, which will make it specific and vivid and easy for students to accurately understand and grasp the main points of aerobics movements. By means of multimedia functions, teachers can help students to create happy learning situations, decompose the difficult aerobics to the students, demonstrate and instruct the students to practice the aerobics efficiently, correct the wrong movements and standardize the aerobics movement in the process of happy interaction. In this process, teachers should make use of various teaching methods, such as case teaching method, project teaching method and hierarchical teaching method, so as to make it interact with the happy teaching method which plays an important role in the class of public sports aerobics, maximize the variety of happy teaching methods, create a new public sports aerobics classroom and coupled theory and practice teaching in real time. Teachers can use the situational teaching method, scientifically set up interesting questions of aerobics topics, effectively guide the students to think effectively, make use of the knowledge of aerobics in the exploration of problemsolving ways, explore their potential in the process of happy interaction and solve the project problems scientifically. The teacher can introduce the role playing method, with the happy teaching method and the features that the students love games and stories, set the funny practice subject of aerobics section, require the students to do role play in a few groups around the theme, effectively access to knowledge, emotion and happy experience in specific situations. At the end of the teaching content, teachers can adopt stratified teaching method, around the concept of happy learning, set up different levels of practice tasks to each group of students, make them perceive the unique charm of aerobics during the process of completing the practice task, cultivate the interest of aerobics and, at the same time, promote the ability of aerobics, which can highlight the application value of the happy teaching method.

\section{CONCLUSION}

In a word, in the process of daily teaching, teachers should correctly interpret the connotation of happiness teaching method, take the concept of happy sports as the medium, introduce the happy teaching method into the teaching of public sports aerobics course and give full play to its diverse role, enhance the interest and interaction of aerobics classes, create a "relaxed and harmonious" classroom, guide and cultivate students' interest in aerobics, make them participate actively in the teaching of aerobics theory and practice and learn aerobics courses happily, develop to be inter-disciplinary talents needed in the new period by shaping the sound personality and publicizing the personality at the same time, and effectively cultivating the physical and psychological qualities. On this account, the teaching value of public sports aerobics course in colleges and universities under the background of education can be promoted to maximization and the higher education enterprise in our country can be developed harmonically.

\section{ACKNOWLEDGMENT}

Jishou University in 2017 field teaching reform project (2017JSUJGB53)

\section{REFERENCES}

[1] Yang Yang. A Study on the Innovative Path of Aerobics Teaching in Colleges and Universities from the Perspective of Practical Theory [J] Journal of Hubei Correspondence University, 2016, 2909: 125-126.

[2] Qian Yang. Innovation and Development of Aerobics Teaching System in Colleges and Universities from the Perspective of Extensive Fitness [J]. Journal of Changchun Education Institute, 2014, 3018: 92+94.

[3] Shanshan Wang. A study on the Ways and Countermeasures of the Reform and Development of Aerobics Teaching in Colleges and Universities [J]. Journal of Chifeng University (Natural Science Edition), 2012, 2810: 135-136.

[4] Ling Ma, Bin Zhou. Application of "Happy Physical Education" in Physical Education Teaching in Colleges and Universities [J]. Course Education Research, 2016, 03: 229-230.

[5] Qingle Zheng, Ming Huang. On the Introduction of the Concept of Happy Sports into the Teaching of Aerobics in Colleges and Universities [J].Contemporary Sports Technology, 2014, 424: 164+166. 